\title{
Latinoamérica y la comunicación periodística española del siglo XX. Naturaleza y alcance de dos ensayos metodológicos*
}

\author{
Alfonso Braojos Garrido \\ Universidad de Sevilla
}

\begin{abstract}
El trabajo responde a los resultados de una amplia investigación practicada con gran parte de la prensa latinoamericana propia del patrimonio documental español y, por otro lado, a los de la cuantificación de más de 65.000 registros de informaciones relativas a Latinoamérica extraídos de la prensa española correspondiente al período 1898-1976. Por su conducto se induce qué parcelas se pueden investigar en España acerca de la realidad de aquel subcontinente a través de sus mensajes periodísticos y, también, qué líneas de información periodística han determinado la comprensión que de Latinoamérica se ha ido formalizando en España en el transcurso del siglo XX.
\end{abstract}

"El cuarto Poder del Estado es, según hemos convenido todos, la Prensa Periódica. Hay quien supone que la susodicha Prensa ascenderá pronto y ganará puestos; pero, por ahora, solamente se le otorga, nemine discrepante, el cuarto lugar. Por la parte que me toca, acepto el sitio y no pretendo otro, ni aun he pretendido ése, por descontado".

A. SÁNCHEZ PÉREZ

La Ilustración Ibérica

(Barcelona, 6 mayo 1893)

Cito, a modo de preludio, estos párrafos de esa revista catalana de fines del siglo pasado porque no creo que exista tema alguno más abierto a debate dentro de los estudios sobre la comunicación pública que el promovido en torno al poder de los medios de prensa y a su influjo en la sociedad. La cuestión, expuesta de forma permanente a lo largo de todo el proceso histórico contemporáneo, estriba en la esencia misma del fenómeno y, por lo que se refiere al ámbito de los mensajes periodísticos, constituye por sí sola, como se sabe, un amplio campo de análisis al plantearse la fuerza persuasiva de aquéllos y su papel en la conducción de las mentalidades y de los comportamientos sociales. Sería, en el marco de las llamadas Ciencias Humanas, el eje de una inagotable dialéctica entre dos

* El texto original de este trabajo se hizo público como ponencia presentada al II Congreso Internacional de Periodismo celebrado en Castellón de la Plana en noviembre de 1994.

Tomo LIV, 2, 1997 
visiones de un único problema, cuya formulación puede resumirse así: ¿en qué términos los testimonios periodísticos representan a los sectores de la sociedad que los genera?, ¿hasta qué extremo los determina su carácter de producto de minorías dirigido a condicionar los criterios del resto de la sociedad? De hecho, algo difícil de resolver, pero apasionante para quienes lo consideramos materia de objetivación en el campo de la Historia. ${ }^{1}$

Aludo a tan complejo asunto en razón a que de él proceden los primeros trabajos que, lejos del positivismo decimonónico, se desarrollaron en la Universidad de Sevilla con documentos de prensa. ${ }^{2}$ Y, también -lo importante ahora-, las inquietudes que dieron pie a dos investigaciones dirigidas a fijar la conexión habida entre Latinoamérica y España a través de la comunicación periodística en los siglos XIX y XX, cuyo contenido resumo en estas líneas. Ambas se definieron como innovadoras en esa parcela de los estudios históricos por su temática y, en especial, por su metodología de soportes informáticos, conjuntando recursos universitarios y de la Hemeroteca Municipal de Sevilla. Y ambas tuvieron su origen en la valoración de unas realidades que forman parte de la contemporaneidad española y que la historiografía más asequible apenas suele destacar: por ejemplo, que a Latinoamérica (Iberoamérica o Hispanoamérica) los españoles le prestaron atención en la prensa ya en la época de las Cortes de Cádiz e, incluso, Blanco White en su El Español allá en el Londres de 1810 a $1814 ;{ }^{3}$ que La América, de Eduardo Asquerino, fue una revista de extraordinaria calidad en la España de 1857 a $1886 ;{ }^{4}$ que La Ilustración Española y Americana, de Abelardo de Carlos, encarnó el más selecto periodismo español de 1869 a 1921, aun antes de los éxitos de Blanco y

1 VV.AA.: Comunicación social y Poder, Madrid, 1993, y Alejandro Pizarroso y otros, Historia de la Prensa, Madrid, 1994.

2 Su impulsor fue Octavio Gil Munilla con una investigación, no concluida, sobre la independencia de Hispanoamérica en la prensa española del reinado de Fernando VII. Para las iniciativas sevillanas y andaluzas, véanse Braojos Garrido, Alfonso: "La prensa de Sevilla: la base actual de su análisis histórico", en Haciendo Historia: Homenaje al Prof. Carlos Seco, Madrid, 1989, págs. 625-631; y "Prensa y <opinión pública> política en la Andalucía contemporánea", en Cuadernos de Comunicación, n. ${ }^{\text {8 }}$, Sevilla, 1991.

3 Lancha, Charles: "La prensa liberal española frente al separatismo hispano-americano", en La Prensa en la revolución liberal. España, Portugal y América Latina, Madrid, 1983, págs. 309-317; y Urrutia, Jorge: "El problema de España y América en Blanco White", en Glosa. Anuario del Departamento de Filología Española, n. ${ }^{2}$, Córdoba, 1991, págs. 367-375.

4 López-Ocón, Leoncio: Biografía de "La América”. Una crónica hispano-americana del liberalismo democrático español (1857-1886), Madrid, 1987. 
Negro, Mundo Gráfico y Nuevo Mundo; que en Cádiz Eduardo de Ory editó, de 1912 a 1936, la revista España y América; o que Huelva tuvo, entre 1911 y 1931, una publicación periódica "colombina iberoamericana", La Rábida, obra de José Marchena Colombo. En sí, un bloque de testimonios que revelan la constante perseverancia española hacia Latinoamérica en su contemporaneidad y que, igualmente, alumbran los cauces periodísticos de difusión de, entre otras, las ideas americanistas del "regeneracionismo" de los hombres "del 98" con Alfonso XIII entre ellos, ${ }^{5}$ las del grupo fundador en 1943 del núcleo de La Rábida o las de intelectuales como Sáinz Rodríguez, Laín Entralgo, Ruiz Giménez, Julián Marías, Manuel Lizcano, etc. o las de las gentes del exilio. ${ }^{6}$ Apreciaciones, en fin, que pueden sintetizarse en estos cinco puntos dignos de una pausada reflexión:

1. $\left.{ }^{\circ}\right)$ Que los estudios de historia de Latinoamérica alentados desde España se sitúan preferentemente y por lo común en la etapa colonial, cuando los siglos XIX y XX nada desmerecen de aquélla (la clave de esa inequívoca situación quizá consista en la enorme riqueza y el atractivo de los fondos que custodia el Archivo General de Indias).

2..$\left.^{\circ}\right)$ Que, pese a lo anterior, consta que los vínculos entre España y Latinoamérica se mantuvieron siempre fluidos en el transcurso de este período, por encima de la pérdida de las colonias - sirvan la emigración y el exilio como muestras-, aunque la guerra antinapoleónica, la eclosión del liberalismo español a raíz de las Cortes de Cádiz y la independencia colonial suscitaron una nueva visión en España respecto de América, distinta a la oficializada por el Antiguo Régimen; un cambio no exento nunca de añoranzas coloniales y al que se incorporaron poco a poco indisimulables recelos hacia el imperialismo norteamericano en el continente. He ahí tal vez la preocupación prioritaria de la España decimonónica por conocer los movimientos desplegados desde Washington en aquel área, con gestos - la correspondencia del embajador García Tassara lo demuestra- que, desde las versiones románticas de la vida hispana y otros engarces de sintonía común, sembraron las primeras pautas de los futuros conSevilla, 1992.

5 Braojos Garrido, Alfonso: Alfonso XIII y la Exposición Iberoamericana de Sevilla de 1929,

6 Fernández Cuesta, Nemesio: América vertebrada, Madrid, 1974; y Abellán, José Luis, y Antonio Monclús (coords.): El pensamiento español contemporáneo y la idea de América, 2 vols., Barcelona, 1989. 
ceptos de "Hispanidad" y de "Raza", término este último consagrado en la jornada del 12 de octubre de $1918 .^{7}$

$3^{\circ}$ ) Que la permeabilidad de España en cuanto a Latinoamérica en esos dos siglos se observa, además, en la constitución de Círculos Hispano-Ultramarinos $^{8}$ (1872-1881) y, por supuesto, en una en principio discreta información periodística, introducida por despachos o correos privados $\mathrm{u}$ oficiales, con espacios de referencia obligada a la guerra entre los Estados Unidos y México (1846-47), las intervenciones extranjeras en México (española y francesa, 1861-67), los conflictos de Paraguay y del Pacífico (1864-69 y 1879-84), y al contencioso sobre la esclavitud. Una información que lógicamente cobró entidad después de que la agencia Fabra se integrase en la francesa Havas (1879), con la ventaja para los promotores en España del new journalism (Ortega Munilla, Polanco, Fernández Flores, Moya, Ducazcal, Luca de Tena y Perojo) de poder exhibir a Latinoamérica en la prensa diaria no sólo en el lugar de la noticia ocasional, sino en el del artículo de opinión, el texto literario y el plano gráfico.

$4^{\circ} .^{\circ}$ Que, según se ha confirmado, semejante giro informativo conoció su inflexión decisiva a partir de 1892, al amparo de los actos del IV Centenario del Descubrimiento de América ${ }^{9}$ - con una revista específica dedicada a la efeméride, El Centenario - y del ascenso noticiable del movimiento de José Martí en una Cuba cuyo destino se iba a dilucidar, junto al de Puerto Rico, en 1898, consumado el "desastre" en la Paz de París.

7 Rama, Carlos M.: Historia de las relaciones culturales entre España y la América Latina. Siglo XIX, México, 1982; VV.AA.: "España y América (1824-1975)", en Cuadernos Hispanoamericanos. Los Complementarios $\backslash 1$, Madrid, 1987; Moreno Juste, Antonio: "Notas sobre el pensamiento ultramarino de Cánovas del Castillo: las Antillas. Crónica de una reforma fracasada (1865-1878)", en Estudios Históricos. Homenaje a los Profs. José M. ${ }^{a}$ Jover Zamora y Vicente Palacio Atard, Madrid, 1990, T. I, págs. 579-599; y Jou, Maite: "Gabriel García Tassara: Del nacionalismo romántico al concepto de raza hispana”, en Anuario de Estudios Americanos, Sevilla, 1993, T. XLIX, págs. 529-562.

8 Arias Castañón, Eloy: "El Centro Hispano-Ultramarino de Sevilla y la guerra de Cuba (1872-1881)", en Temas de Historia Militar, Actas del II Congreso de Historia Militar, Madrid, 1988, T. III, págs. $215-229$.

9 Calderón Quijano, José A.: "El IV Centenario del Descubrimiento en la Ilustración Española y Americana y en el Ateneo de Madrid", en Actas de las V Jornadas de Andalucía y América, Sevilla, 1986, T. II, págs. 1-96; Bernabeu Albert, Salvador: 1892: El IV Centenario del descubrimiento de América en España: Coyuntura y conmemoraciones, Madrid, 1987, y Abad Castillo, Olga: El IV Centenario del Descubrimiento de América a través de la prensa sevillana, Sevilla, 1989. 
Dos episodios éstos de capital significación, que provocaron en España un interés periodístico inusitado por Latinoamérica, bajo el clamor "regeneracionista" de la idea de intentar la "recuperación" de las antiguas colonias por la vía de los lazos económicos, culturales y espirituales; es decir, por los beneficios de la hermandad del mundo hispanoamericano o iberoamericano como réplica al imperialismo yanki de las doctrinas de Cleveland, de Teodoro Roosevelt y de la Unión Panamericana (1909). Y todo eso en un clima receptivo al pretexto de cumplirse en 1910 el centenario de la independencia de las colonias hispanas y, por consiguiente, a un hispanoamericanismo palpable en un Rubén Darío, entre otros, y que logró su manifiesto en la obra Ariel (de La tempestad, de Shakespeare) del uruguayo José Enrique Rodó (1900). ${ }^{10}$

5..$^{\circ}$ Que es notorio cómo ese caudal informativo y de "opinión" se acentuó en pleno siglo XX, en la medida en que España, entre 1911 y 1931, fue capaz de acometer 44 tratados o acuerdos con los países latinoamericanos (2`31 de media al año), abrir allí más de 20 legaciones diplomáticas ${ }^{11}$ e inaugurar la Exposición Iberoamericana de Sevilla (1929). ${ }^{12}$ Sin más, avances mantenidos luego, por décadas, hasta casi nuestros días, con ocasión de la guerra civil española, de la firma de los protocolos hispano-argentinos (1942-52) y del culto indeleble a un "hispanismo" de claros visos económicos, políticos y culturales $;{ }^{13}$ de suyo, un progreso en el que han tenido mucho que ver brillantes corresponsales de prensa y la

10 Reverte Bernal, Concepción: "Hispanoamericanismo 1912-1936 a través de la revista España y América", en Anales de la Universidad de Cádiz II, Cádiz, 1985, págs. 349-366.

11 Martínez de Velasco, Ángel: "Política exterior del Gobierno de Primo de Rivera con Latinoamérica", Revista de Indias, núms. 149-150, Madrid, jul.-dic. 1977; "La reforma del cuerpo diplomático por Primo de Rivera", Revista Internacional de Sociología, 2. época, n. ${ }^{\circ}$ 35, jul.-sept. 1980; y “España e Iberoamérica (1900-1931)”, Proserpina, 1, Mérida, 1984, págs. 51-57.

12 De este certamen existe una amplia bibliografía. El estudio más reciente que la recoge al completo es el de Eduardo Rodríguez Bernal: La Exposición Iberoamericana de Sevilla de 1929, Sevilla, 1994.

13 Espadas Burgos, Manuel: Franquismo y política exterior, Madrid, 1987; Delgado Gómez Escalonilla, Lorenzo: Diplomacia franquista y política cultural hacia Iberoamérica. 1939-1953, Madrid, 1988; González Calleja, Eduardo, y Fredes Limón Nevado: La Hispanidad como instrumento de combate. Raza e imperio en la Prensa franquista durante la Guerra Civil española, Madrid, 1988; y Enrich, Silvia: Historia diplomática entre España e Iberoamérica en el contexto de las relaciones internacionales (1955-1985), Madrid, 1989. También, como exponente de una línea intelectual de opinión en las postrimerías del franquismo, Muñoz Pérez, José: Discurso y reflexiones en torno a la Comunidad Hispánica de naciones. Sus fundamentos, consecuencias y posibilidades, Sevilla, 1982. 
expansión de la agencia EFE auspiciada por Carlos Mendo (1965) y Luis María Ansón (1976). ${ }^{14}$

Cinco puntos, en definitiva, que exteriorizan las apreciaciones antes mencionadas, con los que se podrá coincidir o no, pero que asientan las interrogantes inductoras de la doble investigación que voy a explicar.

\section{Fuentes y metodología}

Una primera, con el título Catalogación, informatización y análisis de la prensa iberoamericanana en España, se asumió institucional y combinadamente por la Hemeroteca Municipal de Sevilla y por el Departamento de Historia de la Comunicación de la Universidad Complutense de Madrid, con dos equipos de especialistas dirigidos por el profesor Jesús Timoteo Álvarez y por quien firma estas líneas. ${ }^{15}$ En la conciencia de lo ineludible de la consulta de los textos periodísticos para la exacta comprensión del proceso histórico contemporáneo, se abordó la conveniencia de construir una base de datos con la prensa latinoamericana localizada dentro de lo que cabría entenderse como el patrimonio documental español, con dos propósitos fundamentales: establecer qué fuentes periodísticas permiten historiar aquel subcontinente dentro de España y, a la par, qué circuitos de comunicación, por conducto de esa prensa, afloran entre ambas orillas del Atlántico a la luz de lo conseguido en la operación anterior. Su puesta en práctica, requirió, desde luego, una ficha de catalogación muy elaborada y un minucioso esquema de trabajo. Ejecutada a lo largo de tres años en 42 archivos, bibliotecas y hemerotecas de 15 provincias españolas e introducida toda la información en un programa informático de soporte Knosys, en la actualidad, y en simple enumeración estadística, su alcance lo refleja el siguiente cuadro que desglosa una cuantificación de títulos pos países:

A) Período cronólogico abarcado: 1791-1991

14 Paz, M. a Antonia: "El predominio matizado de EFE”, en Historia de los medios de comunicación en España. Periodismo, imagen y publicidad (1900-1990) por Jesús Timoteo y otros, Barcelona, 1989, págs. 347-362.

15 Aprobada la investigación por la CICYT en 1989, tales equipos lo integraron, en Sevilla, los profesores María Parias Sáinz de Rozas y Juan Hochberg y, en Madrid, Ascensión Martínez Riaza, Enrique Ríos y Sara Núñez del Prado. 
B) Documentación inventariada:

\begin{tabular}{|c|}
\hline Países \\
\hline Argentina \\
\hline Bolivia \\
\hline Brasil . \\
\hline Colombia \\
\hline Costa Rica . \\
\hline Cuba ..... \\
\hline Chile ..... \\
\hline Rep. Domini \\
\hline Ecuador ... \\
\hline El Salvador \\
\hline Guatemala . \\
\hline Honduras .. \\
\hline México ... \\
\hline Nicaragua . \\
\hline Panamá ... \\
\hline Paraguay .. \\
\hline Perú \\
\hline Puerto Rico \\
\hline Uruguay \\
\hline Venezuela \\
\hline
\end{tabular}

Como se ve, la cifra total obtenida se sitúa en 3.078 fichas de igual número de títulos de periódicos o revistas latinoamericanas. Y estas son las tres conclusiones cardinales que se deducen de su contenido:

1. a) Que España cobija una voluminosa documentación periodística latinoamericana, aunque dispersa y muy fraccionada, con lotes concentrados en su mayoría en Madrid, Sevilla y Barcelona (1.484, 1.414 y 671 unidades respectivamente), en series que permiten historiar Latinoamérica desde España con relativa comodidad -el siglo XX mucho mejor que el XIX - a través tanto de diarios de información general y de revistas literarias o científicas como de los boletines de los centros españoles allí constituidos.

2.a) Que los circuitos de comunicación periodística más dinámicos entre España y Latinoamérica fueron alentados por los lazos entre los emi- 
grantes y sus ciudades natales, los núcleos afines en postulados doctrinales o anhelos artísticos, literarios y científicos, y las efusiones políticas en fechas de exagerada exaltación nacionalista (cuando la Dictadura de Primo de Rivera con la Exposición Iberoamericana de Sevilla de 1929 como paradigma — contó con un Pabellón de la Prensa_- la guerra civil o la armonía Franco-Perón, por ejemplo).

3. ${ }^{\text {a) }}$ Que en esos circuitos se percibe singular fluidez con México, Argentina y Cuba; sones discretos con Colombia, Venezuela, Brasil, Chile, Perú, Ecuador y Uruguay; un tono vivo con Puerto Rico y leve con Paraguay, así como con los países de Centroamérica o el Caribe. En suma, unas relaciones informativas que pueden estimarse exponente de otro tipo de relaciones - humanas, culturales, económicas o políticas - que han habilitado, y aún hoy sostienen, la historia contemporánea de los espacios español y latinoamericano.

Ciertamente, esta investigación no se ha cerrado todavía. Quedan documentos por inventariar. Sin embargo, debe admitirse que el esfuerzo implícito en lo por ella expedido hasta ahora argumenta en términos razonables el dominio de los dos objetivos que la justificaron: la funcionalidad de la metodología informática asegurada en la base de datos abierta (de consulta en la Hemeroteca Municipal de Sevilla); y la búsqueda de una aportación original y provechosa en un horizonte poco explorado en España, el de los estudios históricos sobre las dimensiones de la comunicación pública en los estadios internacionales dentro de la época contemporánea. ${ }^{16}$

La segunda investigación, con el título Análisis y conceptuación de la imagen de Latinoamérica en la prensa española del siglo XX, para una tarea inicial de tres años y bajo la responsabilidad de un Departamento de Historia Contemporánea de la Universidad de Sevilla, incorporado a la recien creada Facultad de Ciencias de la Información, se propuso en planos similares a la anterior y desde tres afanes entusiastas: el sumergirse en nuevas temáticas dentro de la comprensión del siglo $\mathrm{XX}$ sin prescindir del binomio España-Latinoamérica, la confianza en el carácter documental de

16 Detalles más concretos de este trabajo en Braojos Garrido, Alfonso: "Catalogación, informatización y análisis de la prensa iberoamericana en España. Objetivos y balance de una investigación”, en Revista de Extremadura, 10, Segunda Época, Cáceres, ene.-abr. 1993, págs. 33-42. De él se derivaron estas dos obras: Timoteo Álvarez, Jesús: y Ascensión Martínez Riaza, Historia de la prensa hispanoamericana, Madrid, 1992; y Checa Godoy, Antonio: Historia de la prensa en Iberoamérica, Sevilla, 1993. 
las fuentes periodísticas y lo preciso de perseverar en el experimento de las metodologías de naturaleza informática. Eso sí, su orientación se programó hacia la denominada convencionalmente por los especialistas como «Historia de las mentalidades»o, incluso, «Historia de la "opinión pública"», ya que lo pretendido con ella era la acotación de lo divulgado en España acerca de Latinoamérica en los últimos tramos del período contemporáneo y de ahí la imagen o imágenes recibidas por los españoles a través de su prensa.

Queda claro, pues, que entrañaba un objetivo muy ambicioso y nada fácil de satisfacer. Por esta causa, antes del comienzo de la investigación fue necesario el acoplamiento de cuatro cuestiones importantes, no resueltas en principio, para alejarse de probables errores y garantizar la máxima pulcritud de los resultados. A saber:

De entrada, un problema de concepto. ¿Qué se quería decir con Latinoamérica?, ¿qué matices debían primarse de los muchos que concilia ese término - artificial, sin duda - en aras de su concreción inteligible, dado lo tan heterogéneo de aquel vasto subcontinente, diverso y uniforme a la vez?, ¿cómo aprehenderlo de acuerdo con una fórmula coherente? Un problema embarazoso que, tras severos juicios, se zanjó optando por segmentar a Latinoamérica en las cuatro parcelas o facetas más representativas de su fisonomía exterior: los rasgos sociales y económicos, complejos y condicionados por las distintas coyunturas; el cuadro político, de múltiples manifestaciones en su inestable evolución; la creación cultural, estética y literaria, asociada a fuertes personalidades; y la supuesta identidad continental, mostrada por sus tildes específicas y sujeta entre lo estadounidense y lo europeo. Es lo que indujo a que el equipo de investigadores encargado de acometerlo se articulara de manera interdiciplinar, con expertos en Historia de América, en Opinión Pública y en Historia de la Literatura Española e Hispanoamericana, de las Universidades de Sevilla y Complutense de Madrid. ${ }^{17}$

Otra cuestión se circunscribió a un extremo de índole cronológica. ¿A qué secuencia temporal equivalía el siglo XX enunciado?, ¿desde y hasta cuándo extender la cobertura de la investigación? Un asunto con varias soluciones y que se solventó sin mayores inconvenientes al elegirse las

17 Aprobada la investigación por la CICYT en 1990 bajo la dirección del autor de esta síntesis, el equipo lo integraron en Sevilla, los profesores Juan Marchena Fernández (Historia de América), Marta Palenque (Historia de la Literatura Española) y Carmen de Mora Varcárcel (Historia de la Literatura Hispanoamericana); en Madrid, Cándido Monzón Arribas (Opinión Pública). 
fechas de 1898 y 1976 como topes inicial y final. El criterio seguido fue que lo contemplado entre ambas fechas - 1898, año de la Paz de París y momento de emersión de la "crisis" de conciencia y moral que cundió en España por la pérdida de las últimas colonias; y 1976, año del primer viaje de don Juan Carlos I, en su calidad de rey de España, a Latinoaméricaencuadraba la perspectiva de un proceso lo suficientemente locuaz como para aceptarse sinónimo de lo que en nuestros días recibe la calificación de siglo XX suceptible de análisis histórico. Con todo, se vio que tan largo momento carecía en sí mismo de unidad interna, habida cuenta el curso discontinuo de la trayectoria española. Por ello, se subdividió — con poca imaginación si se quiere - en las cinco fases más sobresalientes de su devenir político: la Monarquía parlamentaria de Alfonso XIII (1898-1923); la Dictadura de Primo de Rivera (1923-1930); la II República (1931-1936); la guerra civil (1936-1939); y el gobierno de Franco (1939-1975), aunque esta última, por razones obvias, quedó fraccionada en tres subfases bien diferenciadas (antes del bloqueo internacional, 1939-1945; el bloqueo, 1946-1948; y después del bloqueo, 1949-1975). Por tanto, cinco o siete períodos en los que las directrices españolas hacia Latinoamérica exteriorizaron una andadura no ajena a las vicisitudes nacionales de cada área.

Por su parte, la tercera cuestión se ciñó a decidir con rigor qué fuentes documentales se dedicarían a la investigación. Si con la meta impuesta se trataba de establecer qué imagen o imágenes de Latinoamérica había emitido la prensa de España en el siglo XX, era obligado no olvidar que dicha prensa no se atuvo a una conducta inamovible entre 1898 y 1976, puesto que con frecuencia se modificaron las normas jurídicas reguladoras de su comportamiento (Ley de Policía de Imprenta de 1883, Ley de Jurisdicciones de 1906, disposiciones de Primo del Rivera, decretos de abril de 1931, Ley de Defensa de la República de octubre de 1931, Ley de Orden Público de 1933, Leyes de Prensa de 1938 y 1966), alternándose momentos de "libertad de información" con otros de censura o de "dirigismo", siempre según los imperativos del poder político. Tampoco, que de Latinoamérica podía haberse ocupado esa prensa de modo diferente en los distintos niveles de la producción periodística (diarios de información general; revistas ilustradas; publicaciones doctrinales, de creatividad literaria o estética; etc.). De igual manera, que no cabía confundir lo que en la acción cotidiana de las redacciones se subraya como "importante" o "interesante". En fin, varios factores no superfluos, sopesados antes de seleccionar los documentos plataforma del trabajo. La decisión definitiva fue la 
de acceder al unísono a títulos de la llamada "prensa de masas" (diarios de Madrid y de provincias, de gran tirada y de tendencia ideológica no coincidente) y de la más minoritaria o "de élite" (semanarios o revistas de diversa inspiración), sin eludir cualquier territorio de la geografía nacional.

La cuarta cuestión respondió a lo obligatorio de un esquema de trabajo o modelo de análisis capaz de absorber e interpretar correctamente la amplísima cantidad de información de la prensa elegida. Con este objeto se pensó como lo más idóneo el diseño de una metodología consistente en tres operaciones consecutivas: a) la extracción de la información de las fuentes documentales; b) el ensamblaje de esa información a los epígrafes de una ficha con dos escalas de valoración (de cualificación periodística y de indicación de la importancia concedida por el medio) $;{ }^{18}$ y c) el registro de toda la información (textos periodísticos y datos de la ficha) en un programa informático Software Dbase III abierto a 22 países latinoamericanos y con 103 códigos de temas relativos a lo social, lo económico, lo político, lo cultural y lo accidental o de sucesos. ${ }^{19}$ De hecho, algo apenas experimentado en los estudios más extendidos de historia de la comunicación pública.

Obviamente, con estas cuatro cuestiones controladas, la investigación comenzó sin olvidar la idea motriz del proyecto: si los españoles, entre 1898 y 1976, han/hemos estado recibiendo — de forma sistemática—informaciones y opiniones de Latinoamérica por unos circuitos de prensa escrita, con unos mensajes específicos y con un tratamiento particular, lo consecuente era deducir que la sociedad española ha asimilado sicológicamente una imagen o imágenes de Latinoamérica acordes con tales mensajes, con independencia de su objetividad o falsedad respecto de la Latinoamérica auténtica y real. Desde la hipótesis de una relación causa-efecto comprensible, ¿̨por qué no afrontar el conocimiento de lo ocurrido verdaderamente en virtud de la comunicación periodística?

\section{Resultados}

Hoy los resultados de la investigación pueden simplificarse afirmando que han respondido satisfactoriamente a lo previsto por dos sustanciales motivos: la confección de una metodología capaz de utilizarse en cualquier otro estudio de idéntica factura; y lo que supone la riqueza de los registros

18 La aportó Cándido Monzón Arribas. Véase Apéndice I.

19 Obra de Juan Marchena Fernández. Véase Apéndice II. 
informatizados en una extraordinaria base de datos sobre las informaciones y opiniones vertidas en la prensa de España acerca de todo lo que concierne a Latinoamérica en el siglo XX, distribuidas tanto por períodos como por países, de forma global o en cada uno de los radios temáticos referidos. Tal consideración se fundamenta en lo siguiente:

A) En que se han consultado 105 títulos de periódicos y revistas de diversas épocas y en numerosos centros de documentación. A saber:

1.-El Imparcial (Madrid, 1898-1932)

2.-El Debate (Madrid, 1911-1936)

3.-El Liberal (Madrid-Sevilla, 1893-1936)

4.-El Sol (Madrid, 1922-1936)

5.- Heraldo (Madrid, 1892-1935)

6.-El Noticiero (Zaragoza, 1937-1945)

7.-Amanecer (Sevilla, 1936-1939)

8.-Ambiente (Zaragoza, 1912)

9.-Azul (Zaragoza, 1912)

10.-Eco de Jaén (Jaén, 1935-1936)

11.-Actualidades (Madrid, 1901-1909)

12.-Blanco y Negro (Madrid, 1892-1975)

13.-Alfoz (Córdoba, 1952).

14.-El Alcázar (Toledo-Madrid, 1938-1949)

15.-Alma Española (Madrid, 1903-1904)

16.-La América (Madrid, 1857-1861)

17.-Cervantes (Madrid, 1916-1918)

18.-Arriba (Madrid, 1935-1966)

19.-Correspondencia Diplomática (Madrid, 1963-1966)

20.-Cosmópolis (Madrid, 1928-1937)

21.-Crónica (Madrid, 1934-1935)

22.-Colón y España (Madrid, 1930)

23.-Cuadernos para el Diálogo (Madrid, 1967-1975)

24.-Cuadernos Hispanoamericanos (Madrid, 1917-1925)

25.-Cultura Hispanoamericana (Madrid, 1917-1925)

26.-Eco. Revista de España (Madrid, 1934)

27.-Electra (Madrid, 1901)

28.-Escorial (Madrid, 1940-1943)

29._La Esfera (Madrid, 1914-1926) 
30.-La Estafeta Literaria (Madrid, 1945)

31.-España (Madrid, 1916-1924)

32. - Esto (Madrid, 1934-1935)

33.-Fantasía (Madrid, 1945)

34.-18 de Julio (Madrid, 1954)

35.-Gaceta Política (Madrid, 1908)

36.-Garcilaso (Madrid, 1943-1946)

37.-Gran Mundo Ilustrado (Madrid, 1962-1964)

38. - La Gran Vida (Madrid, 1907)

39.-Hispania (Madrid, 1925-1926)

40.-Horizonte (Sevilla-Madrid, 1938-1940)

41.-La Ilustración Española y Americana (Madrid, 1900-1921)

42.-Índice (Madrid, 1957-1961)

43.-Instantáneas (Madrid, 1900)

44.-Ínsula (Madrid, 1946-1960)

45.-Metrópolis (Madrid, 1933-1934)

46.-Mundo Hispánico (Madrid, 1948-1973)

47.-Mundo Gráfico (Madrid, 1911-1936)

48.-Nuestra Raza (Madrid, 1936)

49.- Pro Patria (Madrid, 1913)

50.-_Reseña (Madrid, 1965-1976)

51.-Nueva España (Madrid, 1930-1931)

52.-Nuevo Mundo (Madrid, 1900-1933)

53.-Revista Crítica de Historia y Literatura española, portuguesa e hispanoamericana (Madrid, 1900)

54.-Revista de las Españas (Madrid, 1929-1931)

55.-Revista Hispanoamericana de Ciencias, Letras y Artes (Madrid, 1924-1932)

56.-Revista de Occidente (Madrid, 1924-1977)

57.-Rumbos (Madrid, 1951-1953)

58.-Surgir (Madrid, 1934)

59.-La Semana Ilustrada (Madrid, 1908-1910)

60.-Unión Iberoamericana (Madrid, 1923-1925)

61.-Unión Patriótica (Madrid, 1926-1930)

62.-Informaciones (Madrid, 1930-1977)

63. - El Siglo Futuro (Madrid, 1892-1930)

64.-Pueblo (1940-1970)

65.-Ya (Madrid, 1935-1936 y 1940-1970) 
66.-Álbum de Salón (Barcelona, 1905-1906)

67.-Cuba en Europa (Barcelona, 1913)

68.-Casa de América (Barcelona, 1924)

69.-Gema (Barcelona, 1929)

70._Los Jueves del Siglo XX (Barcelona, 1900)

71.--Mercurio (Barcelona, 1936)

72.-El Noticiero Universal (Barcelona, 1935-1966)

73.-Panteisme (Barcelona, 1911)

74.-El Productor Hispano-Americano (Barcelona, 1930-1932)

75.-Solidaridad Obrera (Barcelona, 1934-1936)

76.-El Correo Catalán (Barcelona, 1936-1939)

77.-La Mañana (Jaén, 1934-1936)

78.-_Revista Gran Vía (Barcelona, 1960)

79.-_Revista del Ateneo (Jerez de la Fra.,1925-1933)

80.-Isla. Verso y Prosa (Cádiz, 1933-1935)

81.-Claridad (Cádiz, 1935-1936)

82._El Guadalete (Jerez de la Fra., 1935)

83.-La Razón (Barcelona, 1928)

84.-La Información (Cádiz, 1935-1939)

85.-Platero. Verso y Prosa (Cádiz, 1940)

86.-Cádiz Gráfico (Cádiz, 1965-1968)

87.-Cauces (Jerez de la Fra., 1936-1939)

88. - Libertad (Valladolid, 1938-1970)

89.-Meseta (Valladolid, 1928-1929)

90.-Alfar (La Coruña, 1923-1926)

91._El Diario Montañés (Santander, 1920-1938)

92.-Diario Regional (Valladolid, 1938-1939)

93.-El Gráfico (Madrid, 1904)

94.-Azul (Córdoba, 1938-1939)

95.-Ayer (Jerez de la Fra., 1940-1946)

96.-Diario de Cádiz (1934-1939)

97.-Ideal (Granada, 1935-1939 y 1974-1977)

98.-Diario de Huelva (Huelva, 1935-1939)

99._-Odiel (Huelva, 1937-1960)

100.-Ágora (Madrid, 1935-1955)

101.-El Correo de Andalucía (Sevilla, 1900-1931 y 1936-1950)

102._FE (Sevilla, 1936-1946) 
103.-Sevilla (Sevilla, 1946-1976)

104._La Unión (Sevilla, 1918-1931 y 1936-1939)

105.-ABC (Madrid-Sevilla, 1903-1977)

B) En que, hasta 1994, de esa colosal documentación se han extraído 65.133 registros de noticias y de artículos de opinión, cuyas referencias abreviadas y en texto impreso equivalen a 6.000 folios. Y registros -incluyen una pequeña muestra de entre 1853 y 1898 - que, introducidos en el programa informático indicado y pese a los vacíos aún no cubiertos, ofrecen este balance absoluto porcentual para el período 1892-1975:

\begin{tabular}{|c|c|}
\hline $3-1923=47^{\prime} 5 \%$ & \\
\hline $1923-1931=21^{\prime} 0 \%$ & “ \\
\hline $1931-1936=11^{\prime} 9 \%$ & “ \\
\hline $1936-1939=65 \%$ & “ \\
\hline $1939-1946=8 ` 2 \%$ & “ \\
\hline $1947-1948=0^{\prime} 6 \%$ & “ \\
\hline $1948-1975=4^{\prime} 3 \%$ & “20 \\
\hline
\end{tabular}

C) En que en esa información, observada por períodos y respetando las constantes de diez países, destacan estos valores relativos:

1853-1923 (Monarquía parlamentaria de Alfonso XIII)

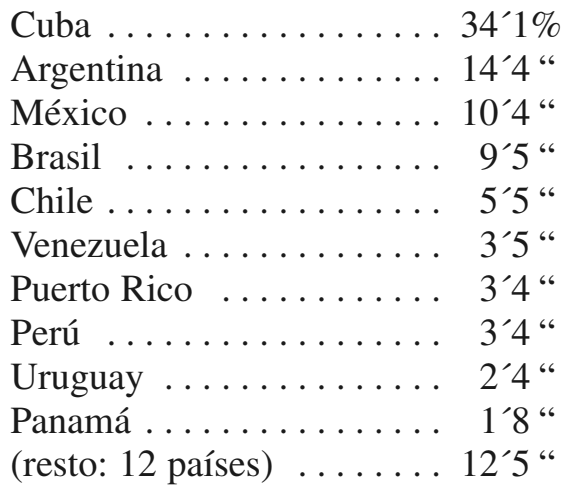

20 Ver apéndice III, gráfico I. Como puede comprobarse, tanto por la documentación manejada como por el período abarcado esta investigación supera la de Javier del Rey Morató, Imagen de América Latina en la prensa española, Madrid, 1987, que se centró sólo en la etapa octubre-diciembre de 1986 y en cinco diarios de Madrid (El País, El Alcázar, Diario 16, Ya y ABC). 
1923-1931 (Dict. de Primo de Rivera)

Argentina $22{ }^{\prime} 4 \%$

México $20{ }^{\prime} 5^{\prime \prime}$

Brasil

$12^{\prime} 2^{\prime \prime}$

Chile

$9^{\prime} 7^{\prime \prime \prime}$

Cuba

6'2“"

Perú

3'6“

Uruguay

$36^{\prime \prime}$

Venezuela

$17^{\prime}{ }^{\prime \prime}$

Puerto Rico

$00^{\prime} 8$

Panamá

$0{ }^{\prime} 8$ “

(resto)

$18^{\prime} 3$ “
México

1936-1939 (Guerra civil)

Argentina

$24^{\prime} 1 \%$

Brasil . .

$19^{\prime} 0 "$

Cuba

$13^{\prime} 8 “$

$10^{\prime} 1$ “

Chile

7’7“

Uruguay

$36^{\prime \prime}$

Venezuela

$2^{\prime} 9$ “

Perú

$2^{\prime} 8$ “"

Panamá

1 '5“

Puerto Rico

$13^{\prime \prime}$

(resto)

$13^{\prime} 2 “$

1947-1948 (El bloqueo internacional)

Argentina $39^{\prime} 5 \%$

México

$10^{\prime} 8$ “

Chile

6'6“"

Cuba

$5^{\prime} 2$ “

Brasil .

$44^{\prime \prime}$

Venezuela

$4{ }^{\prime} 1^{\prime \prime}$

Perú

$1^{\prime} 7$ “"

Uruguay

$1{ }^{\prime} 4$ “"

Panamá

$03^{\prime \prime}$

Puerto Rico

$03^{\prime \prime}$

(resto)
1931-1936 (II República)

Argentina . . . . . . . . 20 20\%

Cuba .............. 18`7“

México ............ 16 16"

Chile .............. 8 8 $8^{\prime \prime}$

Brasil .............. 7’7“

Perú ............... 6" 6"

Uruguay $\ldots \ldots \ldots \ldots$. $4^{\prime} 0^{\prime \prime}$

Venezuela ........... 1'4 "

Panamá ............. 1'2 “

Puerto Rico ........... 0. 0 0 6 "

(resto) ........... 14'5 “

1940-1946 (1. ${ }^{\circ}$ franquismo)

Argentina . . . . . . . . . 40 40 $9 \%$

Chile .............. 13'1"

México ............ 13’0"

Brasil .............. . 7'1 “

Cuba .............. 4'3“"

Perú .............. 377"

Uruguay $\ldots \ldots \ldots \ldots$ 2'7 “

Venezuela ........... 1'8

Panamá .............. 0 0 9 “

Puerto Rico . . . . . . . . . . 0. 0 $0^{\prime}$ “"

(resto) ........... 12'1 “

1949-1975 (2. ${ }^{\circ}$ franquismo)

Argentina . . . . . . . . 23\%

México ............ 17'8 “

Brasil .............. 8 8’3“

Cuba .............. 7'9

Chile .............. 6 6'8 "

Perú .............. 5' $3^{\prime}$ “

Venezuela ........... 5 5 ${ }^{\prime} 0^{\prime \prime}$

Uruguay $\ldots \ldots \ldots \ldots \ldots$ 2' $8^{\prime \prime}$

Panamá ............ 2’0

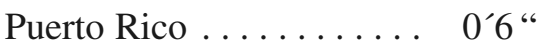

(resto) . . . . . . . . 19 19'9

21 Véase Apéndice III, gráficos II-VIII.

708

Anuario de Estudios Americanos 
D) En que esa información, estructurada por períodos y conforme a seis bloques de contenidos, marca el siguiente orden de referencias en lo publicado:

1853-1923

Política ............ 57’6\%

Economía ............ 18`3“

Cultura .............. 10'2“

Sociedad ............. $7^{\prime} 0 "$

Sucesos ............. 5 5 "

Pensamiento ........... 1'5 “

$1923-1930$

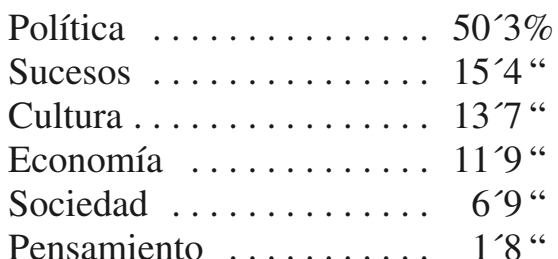

$1936-1939$

Política ...........6 64'5\%

Sucesos ............ $8^{\prime} 8$ “

Economía ........... $8^{\prime} 77^{\prime \prime}$

Sociedad ........... $7^{\prime} 9^{\prime \prime}$

Cultura ............. 7'3 "

Pensamiento ......... 2'8“

1947-1948

Política ........... 66 66\%

Cultura .............. 20 201 “

Sucesos ........... $5^{\prime} 0$ "

Economía ........... 4 4'4 "

Sociedad ........... 3' ${ }^{\prime}{ }^{\prime \prime}$

Pensamiento ......... $0^{\prime} 6$ “

22 Véanse Apéndice III, gráficos IX-XV.

Tomo LIV, 2, 1997

709
Política .............. 55’3\%

Economía . . . . . . . . 13 13 “ “

Sucesos ............ 11'2“

Cultura ............ 10 100"

Sociedad ............ 7' $7^{\prime} 9^{\prime \prime}$

Pensamiento ......... 1'7“

1940-1946

Política ........... 55'5\%

Cultura ............ 15'8 “

Economía . . . . . . . . . 10 109 “

Sociedad ........... $7^{\prime} 0^{\prime \prime}$

Sucesos ............ 6 6 6

Pensamiento ......... 3'9 “

1949-1975

Política ........... 47'3\%

Cultura . . . . . . . . . 27'5 “

Sucesos ........... 13'6"

Sociedad ............ 6 6 $6^{\prime \prime}$

Economía ........... 4'5 “

Pensamiento ......... $0^{\prime} 9^{\prime \prime 22}$ 


\section{Conclusiones}

Como pueden contemplarse, unos resultados traducidos en cifras, tabuladas siempre en valores relativos. Parece claro que indican una realidad por ahora sólo admisible con ciertas reservas en su demostración científica, teniendo en cuenta la fase en que se halla la investigación, pendiente aún de consultas más prolijas en los documentos de las etapas franquistas. De cualquier manera, en 1997 la cifra de registros se eleva ya a 89.228. Con todo, se convendrá que existen datos suficientes como para aventurar unas conclusiones provisionales que, de seguro, no se distanciarán demasiado con las que se anuncien en su día como definitivas. Serían estas:

1. $\left.{ }^{\circ}\right)$ Que, al margen de las normas jurídicas en vigor en cada período, la información y los artículos de opinión sobre Latinoamérica insertos en la prensa española —entendida en sentido lato - del siglo XX decaen ostensiblemente en intensidad a partir de la proclamación de la II República, en razón, entre otras causas, a asumirse la pérdida de las últimas colonias (Cuba y Puerto Rico), la baja en el énfasis del debate "regeneracionista" acerca del sentido de la "Hispanidad" o del "iberoamericanismo" tras la Exposición de Sevilla de 1929 y la no repetición de episodios tan prolongados como la revolución mexicana (1910-1934). ${ }^{23}$ De cualquier modo, su interés como materia de difusión se mantuvo desde 1931 con regularidad, si bien con ecos más templados y, en conjunto, en tono inferior a los de comienzos de la centuria.

$\left.2^{\circ}{ }^{\circ}\right)$ Que tanto esa información como los artículos de opinión concentraron siempre sus ángulos prioritarios en torno sólo a cinco países (Argentina, México, Cuba, Brasil y Chile), alternándose el orden de protagonismo en función de sus incidencias internas y de su grado de vinculación política, económica o "espiritual” a España (simpatías Franco-Perón, por ejemplo). ${ }^{24}$ En concreto, Argentina y México —este último encabeza los por-

23 El primer período abarcado en esta investigación y desde una referencia local lo clarifica la obra de María José Ruiz Acosta: Sevilla e Hispanoamérica. Prensa y opinión pública tras el Desastre de 1898, Sevilla, 1996; e Hispanoamérica en la Sevilla de comienzos del siglo XX (Prensa y opinión pública). 1898-1914. Tesis de Doctorado inédita, Uni. de Sevilla, 1996. Ambos estudios enlazan con el de Rosario Sevilla Soler: La Guerra de Cuba y la memoria colectiva. La Crisis del 98 en la prensa sevillana, Sevilla, 1996.

24 Delgado Gómez-Escalonilla, Lorenzo: Imperio de papel. Acción cultural y política exterior durante el primer franquismo, Madrid, 1992 (con abundante bibliografía); Pérez Montfort, Ricardo: Hispanismo y Falange. Los sueños imperiales de la derecha española y México, México, 1992; y Mularska-Andziak, Lidia: "Pan-hispanismo 1939-1943: ¿un desafío para el pan-americanismo?”, en Idearium, vol. I, Málaga, 1992, págs. 91-100. 
centajes en la etapa de la guerra civil- aparecen como los dos focos principales de los predicamentos publicados, por delante de Cuba, Brasil y Chile, mientras 17 Estados latinoamericanos (Guatemala, El Salvador, Paraguay, Ecuador, Bolivia, Honduras, etc.) quedan en un muy segundo plano y a expensas de sucesos esporádicos o de convulsiones violentas (la Guerra del Chaco, 1932-1935). Llaman la atención Puerto Rico, de la que por sistema se ensalza su españolidad, y Panamá, prueba de la presencia imperialista de Estados Unidos en aquel subcontinente.

3..$^{\circ}$ Que la línea temática predominante en esa información y en los artículos de opinión es, con mucho, la que alude a los acontecimientos y a las actitudes políticas, que nunca desciende por debajo del $47 \%$ de lo divulgado, observándose, en ocasiones, a la prensa española caer en lo definido por algunos tratadistas de "politicolatría" y de "conflictolatría". Sería el reflejo de una Latinoamérica noticiable de forma continua por su propia inestabilidad interna y por la dureza de su agitado mundo político. No obstante, en esta supremacía de los textos políticos lo que se manifiesta con frecuencia son acciones de aproximación o de rechazo del gobierno español alumbradas sobre el telón de fondo de algún país latinoamericano. Es lo que motiva el realce, varias veces, de la información de contenido económico (tratados comerciales con Uruguay, Brasil, Argentina, Colombia, etc.), pues la riqueza y la potencialidad de los recursos de Latinoamérica jamás se dejan de alabar.

4..$^{\circ}$ Q Que esa información encuentra un pozo inagotable para exhibir un espectacular sensacionalismo en el capítulo de "sucesos", con especial alarde tipográfico cuando se ocupa de catástrofes naturales (terremotos), accidentes (colisión o hundimientos de barcos, derrumbes en minas, incendios), noticias de la llamada "crónica negra" (crímenes, raptos, asaltos) y hasta apariciones de ovnis. Acontecimientos que, al igual que los conflictos políticos, sirven, por lo común, de preámbulo a comentarios acerca de las duras condiciones de vida y de los contrastes socioeconómicos de la población latinoameriana; tema este que, por sí mismo, en rara oportunidad adquiere relieve con ánimo sincero.

5..$^{\circ}$ Que toda la información y los artículos de opinión mantienen con savia inalterable las energías de un discurso plagado de elementos sentimentales, al que contribuyen políticos, escritores de prestigio, universitarios, artistas y la audacia de insólitas empresas (actores, cantantes, bailarines, toreros, aviadores); discurso en el que se mezclan lo propiamente 
americano —el indigenismo y los parajes selváticos se ponderan como algo pintoresco y exótico-, lo "hispanoamericano" y lo "occidental". Cristalizaría en el panel comunicativo de la cultura y de los "valores", donde coinciden el canto a la benéfica labor colonizadora de España allí, con la evangelización en plano sublime, la penosa o fructífera presencia de los emigrantes y la obra de ilustres personalidades. Un todo, donde se dan cita dos grandes cargas de intencionalidades: la de la excusa para un pretendido nacionalismo verbal; y la de lo simbólico del "genio hispano", dilatado éste en los contactos entre intelectuales españoles y latinoamericanos y al que colaboran ya la concesión del Premio Nobel de Literatura a Gabriela Mistral (1945) y a Miguel Ángel Asturias (1967), ya la herencia estética de Darío, Lugones, Huidobro, Borges, etc. y el "boom" narrativo de la década de 1960 (Carpentier, Onetti, Sábato, Fuentes, Vargas Llosa, García Márquez, Cortázar, Lezama, etc.), de cuya popularidad se hace portavoz la prensa. ${ }^{25}$ Pero un discurso emitido con altibajos - recuérdense los porcentajes de los apartados de Cultura y Pensamiento-, sujeto a elementos abstractos e irracionales, retórico, reiterativo, sumergido en la metáfora y la hipérbole, que de ser producto de minorías concluye por acuñar abundantes tópicos.

6. $\left.{ }^{\circ}\right)$ Que de esa información y de los artículos de opinión los españoles del siglo XX han recibido de Latinoamérica no una única imagen, sino numerosas imágenes, muy contradictorias y dispersas en los distintos planos de la comunicación periodística, a la que contribuyen agentes españoles y latinoamericanos. La de un subcontinente preso de la inestabilidad política, aunque modélico a ráfagas en algunos de sus regímenes; soberano, pero bajo el control de los Estados Unidos; pudiente y generoso en medios, abierto a óptimas posibilidades y, sin embargo, necesitado de apoyo para el logro de su prosperidad; cuna de talentos y creativo, aunque lleno de injusticias y de miserias incalificables; leal $\mathrm{y}$, sin embargo, pleno de cautelas hacia la que fuera su antigua metrópoli, España. Consecuentemente, unas imágenes muy compartimentadas en el espacio, el tiempo y los contenidos, que nunca superan el desequilibrio entre el tratamiento periodístico de los hechos y la mitificación de los "valores históricos", que no profundizan auténticamente en Latinoamérica y que lo más que consiguen es que su confusa existencia

25 Sobre la cuestión, "Las relaciones literarias entre España e Iberoamérica", Actas del XXIII Congreso del Instituto Internacional de Literatura Iberoamericana, Madrid, 1987. 
no haya resultado extraña a la sicología colectiva de los españoles a lo largo del siglo XX.

Cierro aquí estas sucintas notas sobre las dos investigaciones que, modestamente, he coordinado desde 1989. Su filosofía, métodos y alcance los he expuesto con brevedad. Y si, como resaltó el expresidente argentino Raúl Alfonsín en 1985, — “las grandes comunidades de naciones, unidas por el origen, la lengua o la cultura no deben perder su singularidad... pero la defensa de su propia identidad no puede ser excluyente, sino constituir un aporte más al enriquecimiento de la civilización humana en su conjunto", ${ }^{26}$ fueron sus palabras-, el mundo camina hacia una justa integración internacional, creo que con empeños intelectuales como los implícitos en ellas se participa en ese proceso, puesto que España y Latinoamérica en esa meta, a través del poder de su acción periodística y del conocimiento histórico de su intercomunicación en el pasado más reciente, tienen mucho y bueno que decir.

26 Alfonsín, Raúl: América Latina y el nuevo orden internacional, Conferencia inaugural del Campus Internacional, Oviedo, 19 de octubre de 1991, La Nueva España, Oviedo, 1991, pág. 15. 


\section{Apéndice I}

FICHA DE REGISTRO ELABORADA PARA LA INVESTIGACIÓN

Periódico

Fecha
Lugar de edición

Escala de valoración

Positiva Negativa

Escala periodística

\begin{tabular}{|c|c|c|c|c|c|c|c|c|c|c|c|c|c|c|c|c|c|c|}
\hline & & & ala & pe & rioc & íst & & & & + & & & & & & - & & \\
\hline Texto & I & 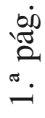 & & . & $\begin{array}{l}\pi \\
0 \\
0 \\
0 \\
0\end{array}$ & $\overline{8}$ & 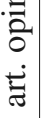 & $\begin{array}{c}\mathbb{a} \\
\tilde{\Xi} \\
\vdots \\
\Xi\end{array}$ & Líneas & 3 & 2 & 1 & 0 & 1 & 2 & 3 & $\mathrm{x}$ & Código \\
\hline & & & & & & & & & & & & & & & & & & \\
\hline & & & & & & & & & & & & & & & & & & \\
\hline & & & & & & & & & & & & & & & & & & \\
\hline & & & & & & & & & & & & & & & & & & \\
\hline & & & & & & & & & & & & & & & & & & \\
\hline & & & & & & & & & & & & & & & & & & \\
\hline & & & & & & & & & & & & & & & & & & \\
\hline & & & & & & & & & & & & & & & & & & \\
\hline & & & & & & & & & & & & & & & & & & \\
\hline & & & & & & & & & & & & & & & & & & \\
\hline & & & & & & & & & & & & & & & & & & \\
\hline & & & & & & & & & & & & & & & & & & \\
\hline & & & & & & & & & & & & & & & & & & \\
\hline & & & & & & & & & & & & & & & & & & \\
\hline & & & & & & & & & & & & & & & & & & \\
\hline & & & & & & & & & & & & & & & & & & \\
\hline & & & & & & & & & & & & & & & & & & \\
\hline & & & & & & & & & & & & & & & & & & \\
\hline & & & & & & & & & & & & & & & & & & \\
\hline & & & & & & & & & & & & & & & & & & \\
\hline & & & & & & & & & & & & & & & & & & \\
\hline
\end{tabular}




\section{Apéndice II}

Campo: Valoración: Tomando como base el 5 (neutro), disminuir hasta 1 la valoración negativa de la información o incrementar hasta 9 la valoración positiva de la noticia. Entiéndase que el uso de estas valoraciones ha de realizarse con la debida cautela. Lo lógico es que la mayoría de las noticias tengan valoración 5 .

Campo: País.

AG-Hispanoamérica en general.

$\mathrm{CE}-$ Centroamérica en general.

AS-América del Sur en general.

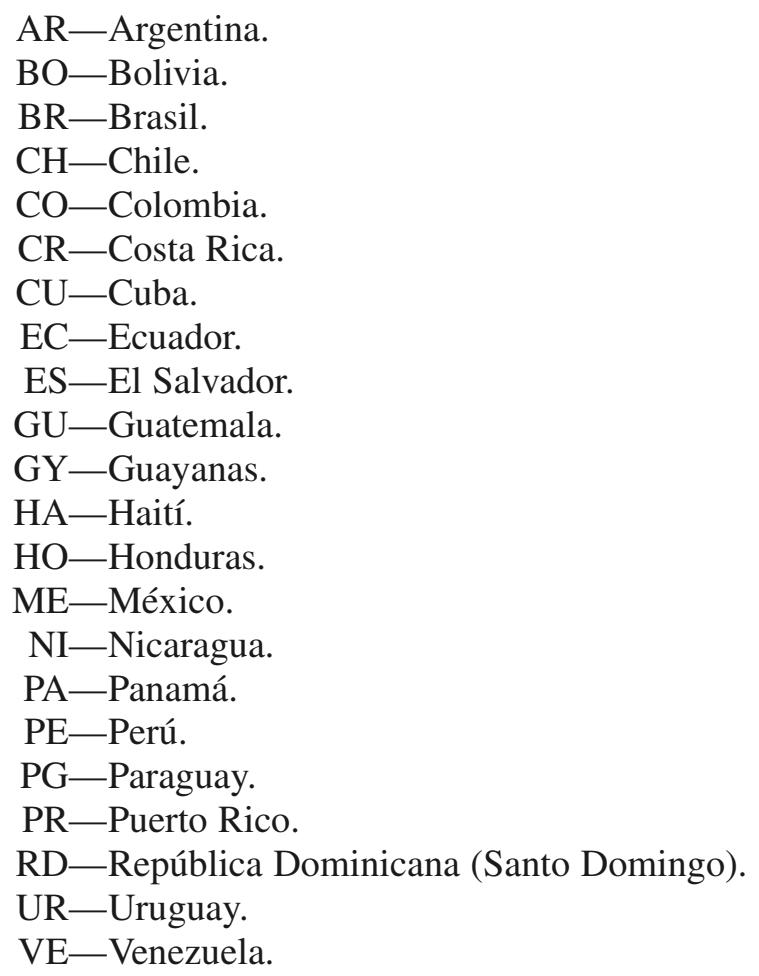




\section{Campo: Códigos.}

Los Códigos serán siempre de cuatro cifras y se separarán con un punto entre ellos. Por ejemplo: .1456.1567.1789.1987.

Caso de no hacerse así serán irrecuperables, o generarán confusiones y errores en la búsqueda de información. Por ejemplo: pidiendo la cadena /.12/ se listarán todas las noticias sobre política exterior. Las convenciones son las siguientes:

.1000.-Política en general.

.1100.-Política interior en general.

.1110.-Proclamación de gobiernos o tomas de posesión.

.1111.-Revoluciones o golpes de Estado.

.1112.-Medidas gubernativas de especial carácter.

.1113. - Partidos o grupos políticos.

.1114.-Relaciones Estado-Iglesia.

.1115. - Conflictos militares internos. Fuerzas armadas.

.1116.-Visitas de políticos.

.1117.-Movimientos guerrilleros.

.1200.-Política exterior.

.1210.—Relaciones diplomáticas entre estados.

.1211. - Guerras entre estados americanos.

.1212.-Conflictos fronterizos sin declaración de guerra.

.1213. - Guerras con otros países no americanos.

.1214.- - Relaciones con España.

.1215.-Relaciones con Europa.

.1216. - Relaciones con Estados Unidos.

.1217. - Relaciones con otros países no incluidos.

.1218. - Tratados entre países americanos.

.1219.-Conferencias o encuentros panamericanos.

.1220.-Participación de países americanos en otros tratados.

.2000.- Sociedad americana en general.

2001.-Clases sociales.

2002.-Inmigración/emigración.

2003. - Problema indígena.

2004.-Condiciones de vida/laborales.

.2005.-Asistencia social. 
.2006.-Movimiento obrero/sindicalismo.

.2007. - Gremios y corporaciones.

.2008.-Modas.

.2009.-Elites.

.2010.-Mujer.

.2011._-Vida cotidiana.

.2012._Vivienda/urbanismo.

.2013. - Medio rural/campesinado.

.2014.-Población.

3000.-Economía en general.

.3100.-Producción en general.

.3101.-Agricultura.

.3102.-Ganadería.

.3103.-Industria.

.3104.-Minería.

3105.-Servicios.

.3106.-Agroindustrias.

.3107.-Artesanías.

.3108.-Pesca.

3200.-Comercio exterior en general.

.3201.-Importaciones.

.3202.-Exportaciones.

.3203.-Monoproducto.

.3204.-Comercio con España.

.3300.-Comercio interior en general.

.3301.-Comercio interior dentro del país.

.3302.-Comercio interior dentro de América.

.3400.--Inversiones en general.

.3401.- Inversiones entre países americanos.

.3402.-Inversiones españolas.

.3403.-Inversiones extranjeras.

.3500.-Compañías extranjeras.

.3501.-Compañías españolas.

.3600.-Comunicaciones en general.

.3601.-Ferrocarril.

.3602.-Carreteras/automoción.

3603.-Navegación/compañías de/navíos.

3604.-Aviación/compañías de.

.3605.- -Vías de comunicación. 
.3700.-Técnica aplicada al desarrollo económico. Inventos. Tecnología.

.4000.-Cultura en general.

.4100.-Creación artística en general.

.4110.-Expresiones literarias (general).

$\begin{array}{llll}.4111 .- & \text { “ } & \text { “ } & \text {.Novela. } \\ .4112 .- & \text { “ } & \text { “ } & \text {.Ensayo. } \\ .4113 .- & \text { “ } & \text { “ } & \text {.Teatro y representación. } \\ .4114 .- & \text {.Poesía. }\end{array}$

.4120.-Artes plásticas en general.

.4121._ " " ". .Pintura.

.4122.- " " " Escultura.

.4123. - " “ " Arquitectura.

.4124._ " " "

.4125.- " " .Cine.

.4130.-Folklore en general.

.4131.-Folklore nativo.

.4132.-Folklore español en América.

.4200.-Encuentros y reuniones culturales y científicas.

.4300.-Deportes.

.4400.- - Noticias sobre prensa/revistas/otros medios de com.soc.

.4500.-Idioma español en América.

.4600._Educación/pedagogía/enseñanza.

.5000.-Pensamiento en general.

.5100.—Filosofía.

.5200.-Pensamiento americano sobre América. Identidad americana.

.5300.—Pensamiento político/social/económico americano.

.5400.- Indigenismo.

.5500 . - Hispanismo.

.5600.-Nacionalismo. Pensamiento/doctrina nacional.

.6000.- Sucesos en general.

.6100.-Catástrofes colectivas.

.6200.-Accidentes.

.6300.-Delincuencia.

.6400.-Asesinatos políticos.

J. MARCHENA 


\section{Apéndice III}

\section{GRÁFICO I \\ DISTRIBUCIÓN DE NOTICIAS POR PERÍODOS \\ 1853-1975}

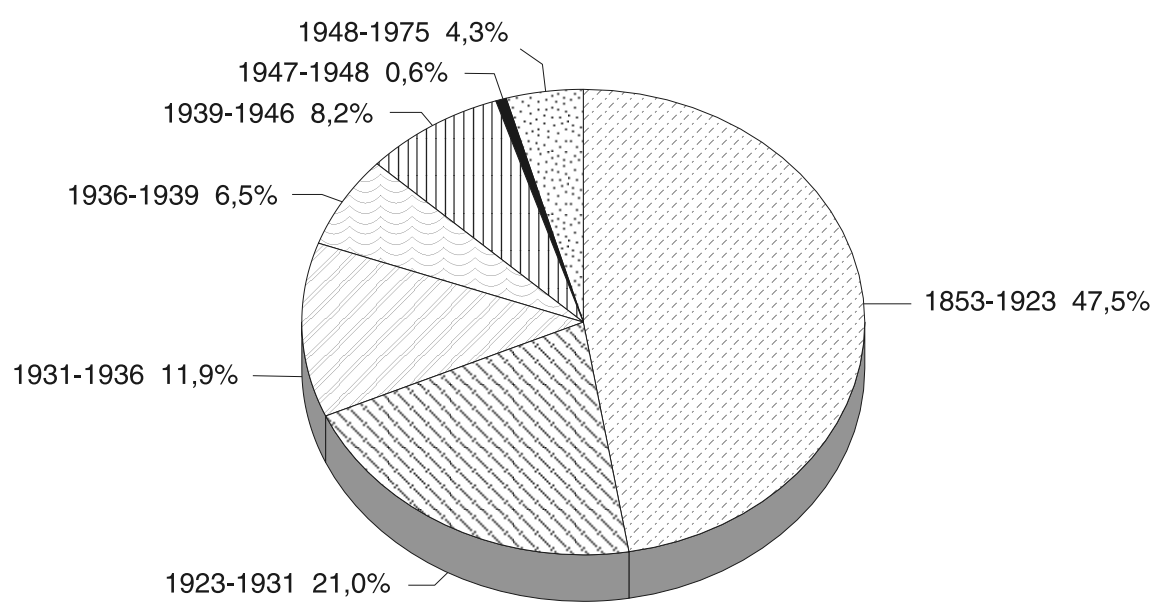

GRÁFICO II

DISTRIBUCIÓN DE NOTICIAS POR PAÍSES

1853-1923

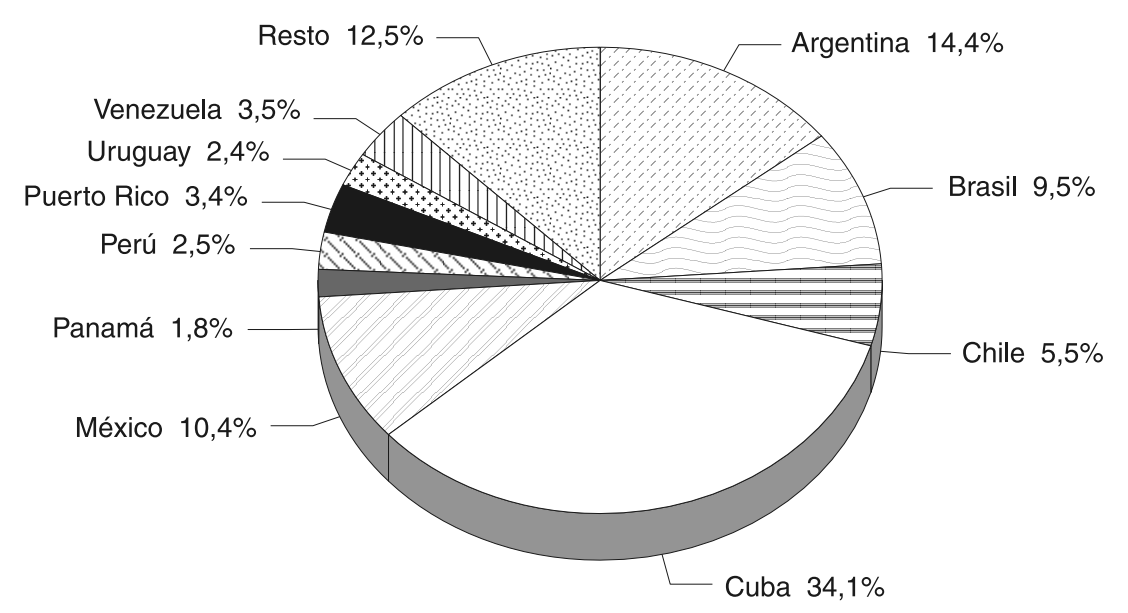




\section{GRÁFICO III \\ DISTRIBUCIÓN DE NOTICIAS POR PAÍSES \\ 1923-1931}

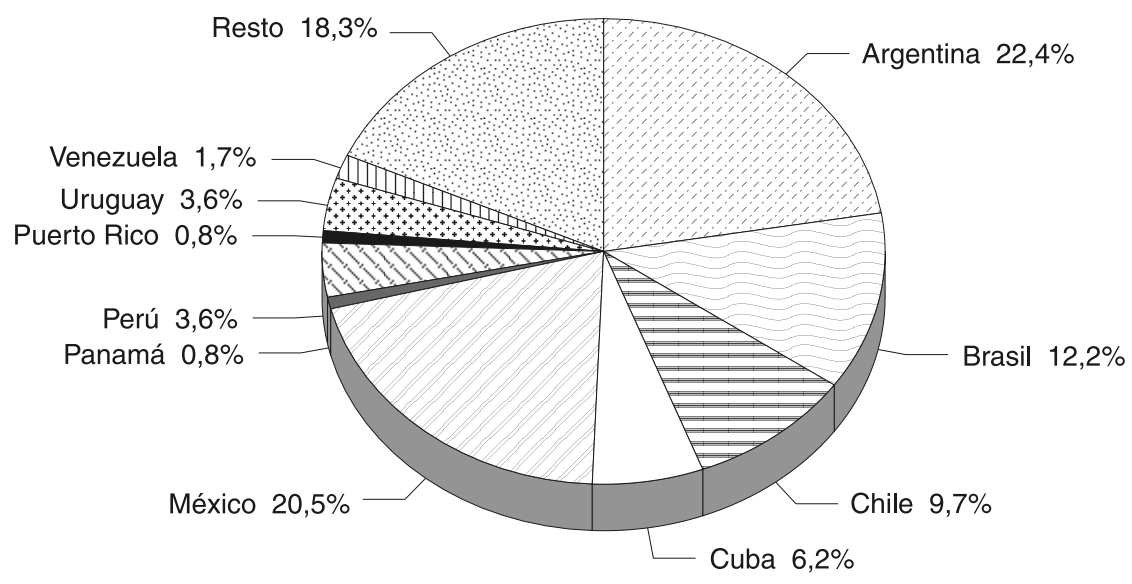

GRÁFICO IV

DISTRIBUCIÓN DE NOTICIAS POR PAÍSES

1931-1936

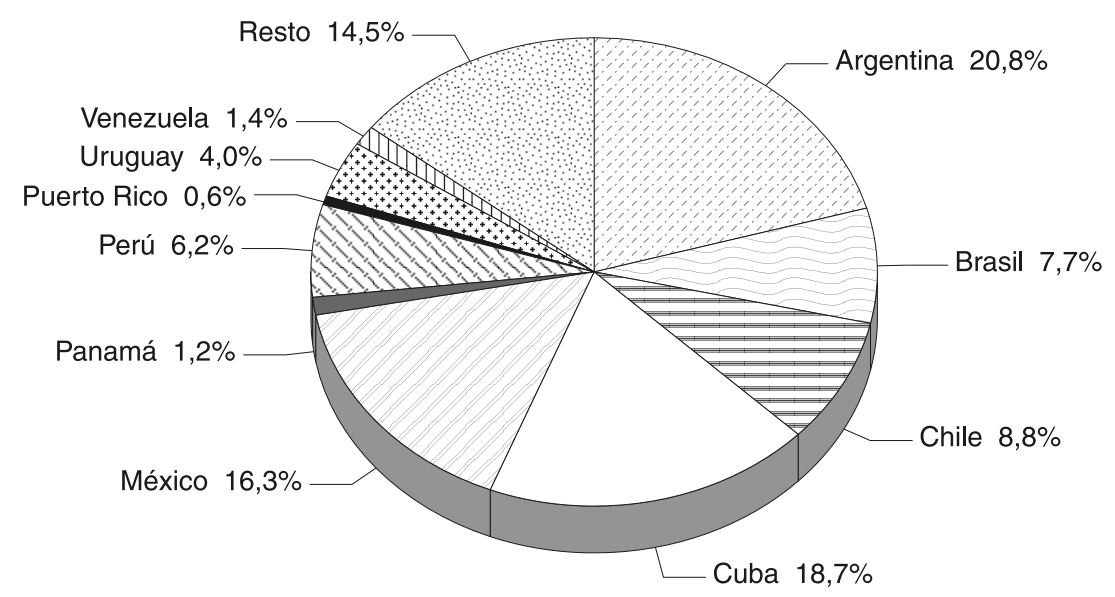

Tomo LIV, 2, 1997 


\section{GRÁFICO V \\ DISTRIBUCIÓN DE NOTICIAS POR PAÍSES \\ 1936-1939}

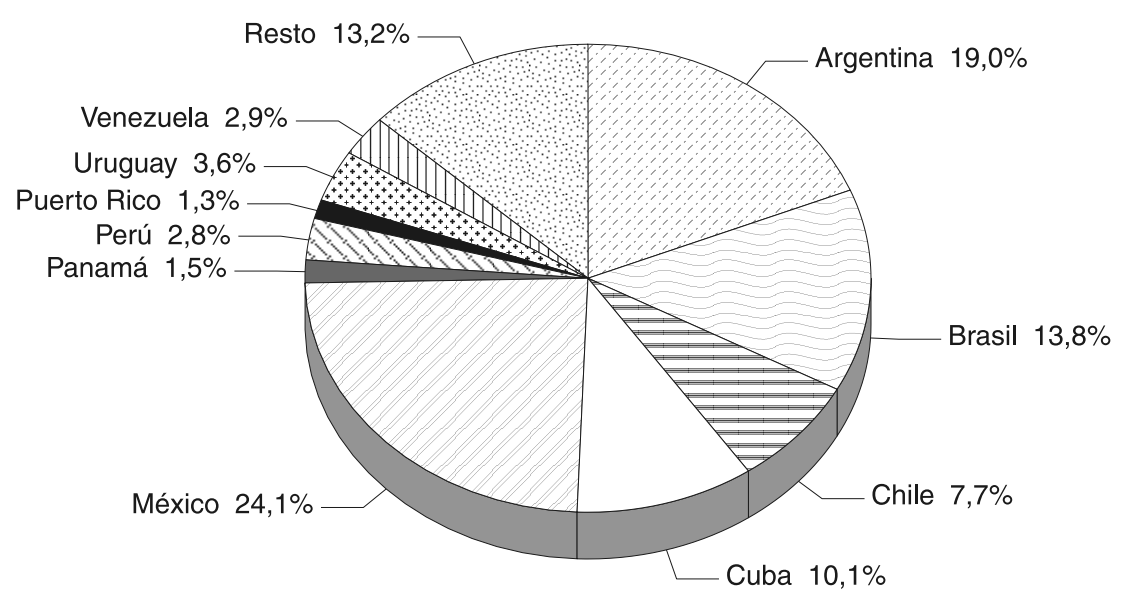

GRÁFICO VI

DISTRIBUCIÓN DE NOTICIAS POR PAÍSES

1940-1946

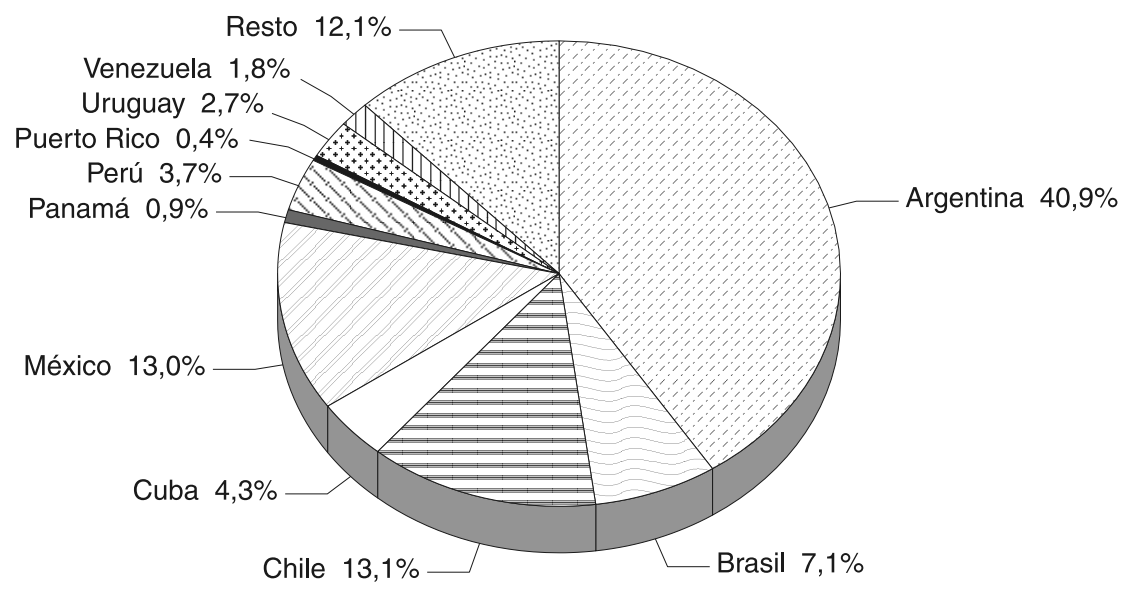




\section{GRÁFICO VII \\ DISTRIBUCIÓN DE NOTICIAS POR PAÍSES \\ 1947-1948}

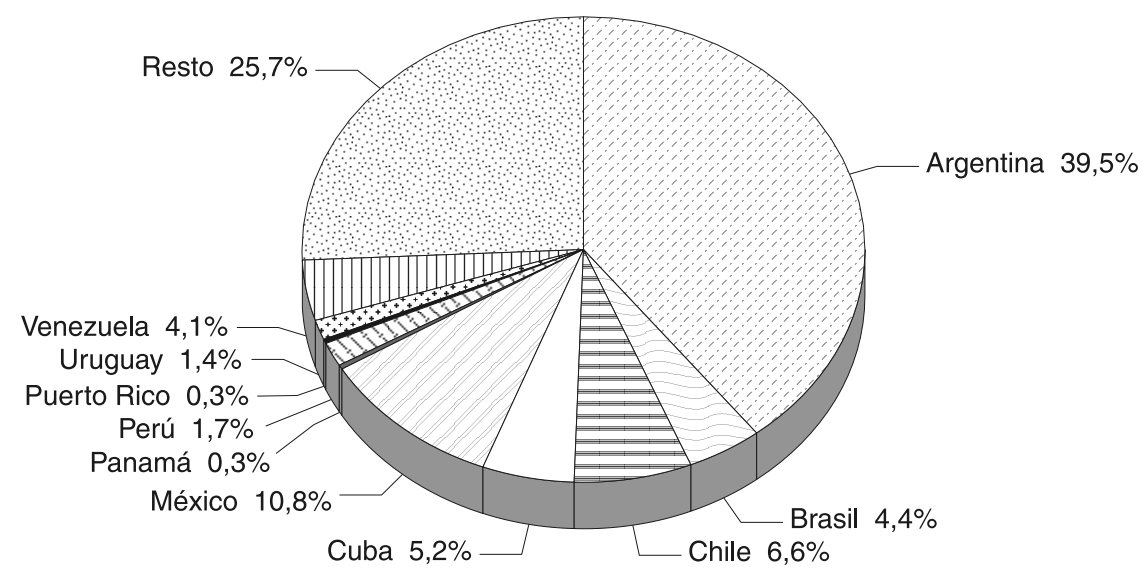

GRÁFICO VIII

DISTRIBUCIÓN DE NOTICIAS POR PAÍSES

1949-1975

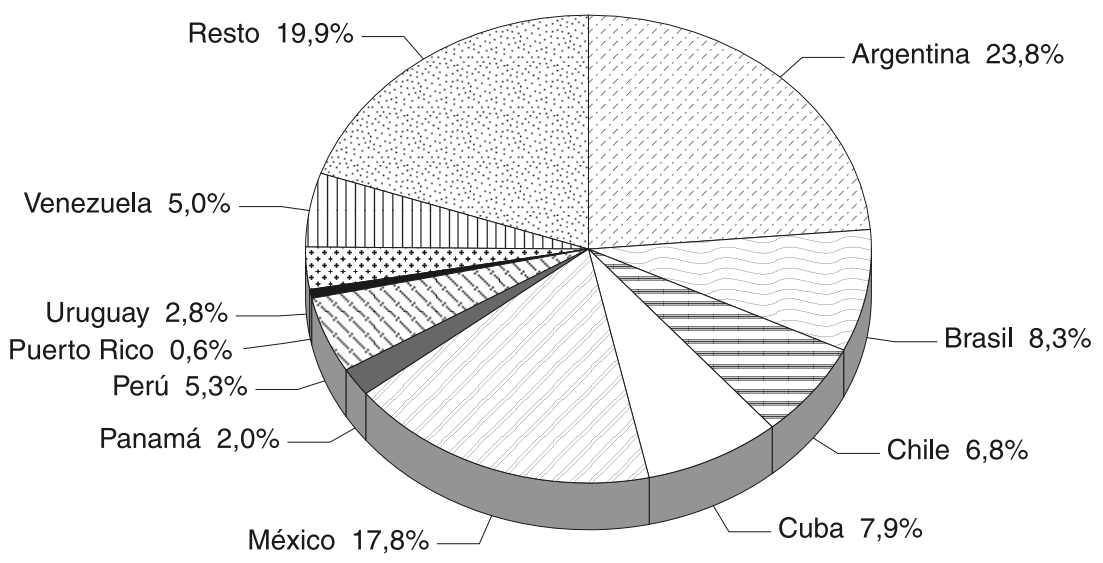




\section{ALFONSO BRAOJOS GARRIDO}

\section{GRÁFICO IX}

\section{DISTRIBUCIÓN DE NOTICIAS SOBRE IBEROAMÉRICA}

De 1853 a la dictadura de Primo de Rivera

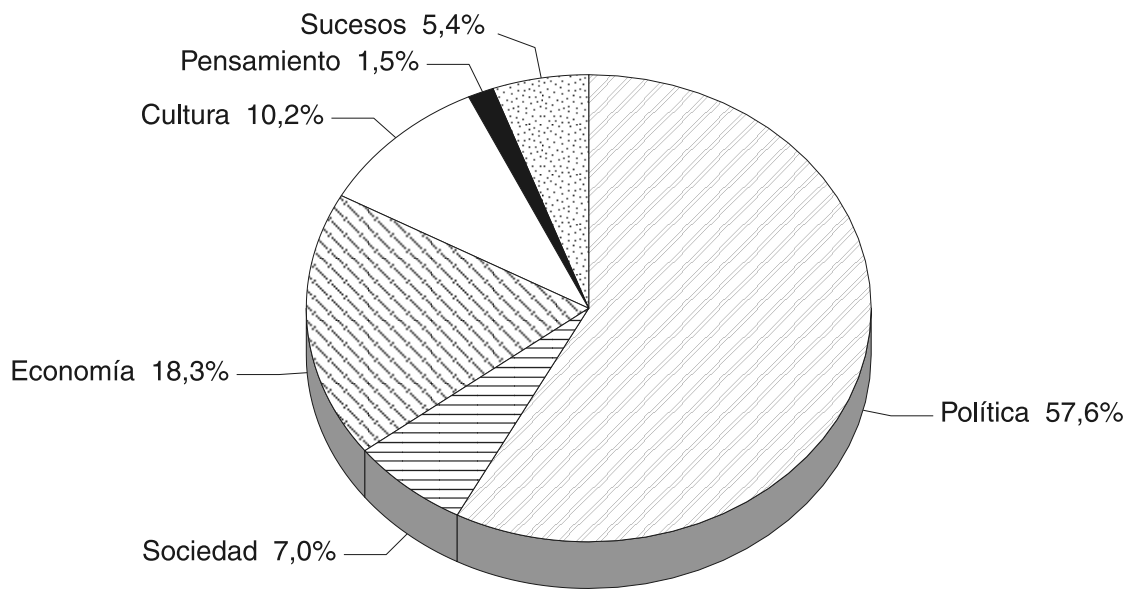

PERÍODO I

\section{GRÁFICO X}

DISTRIBUCIÓN DE NOTICIAS SOBRE IBEROAMÉRICA

De la dictadura de Primo de Rivera a la República

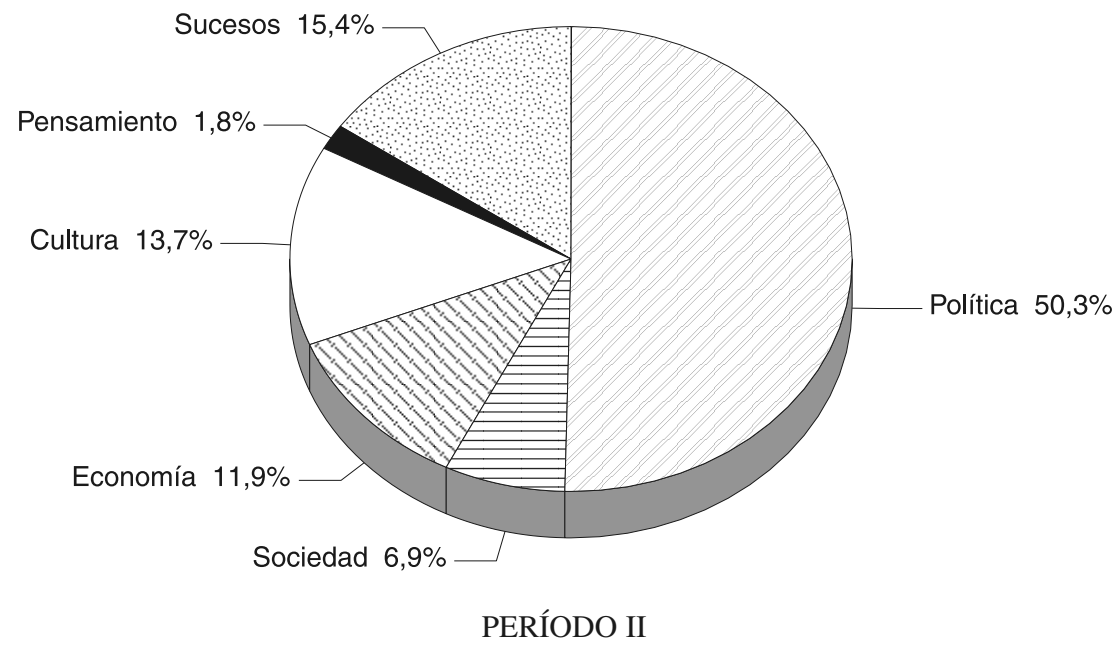


GRÁFICO XI

DISTRIBUCIÓN DE NOTICIAS SOBRE IBEROAMÉRICA

La República

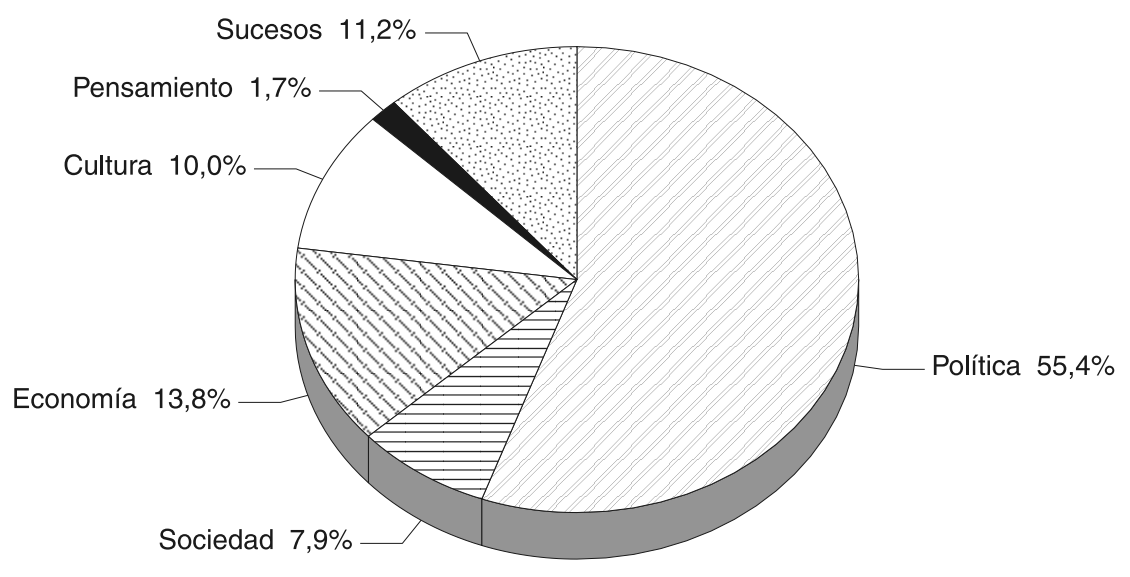

PERÍODO III

GRÁFICO XII

DISTRIBUCIÓN DE NOTICIAS SOBRE IBEROAMÉRICA

La Guerra Civil

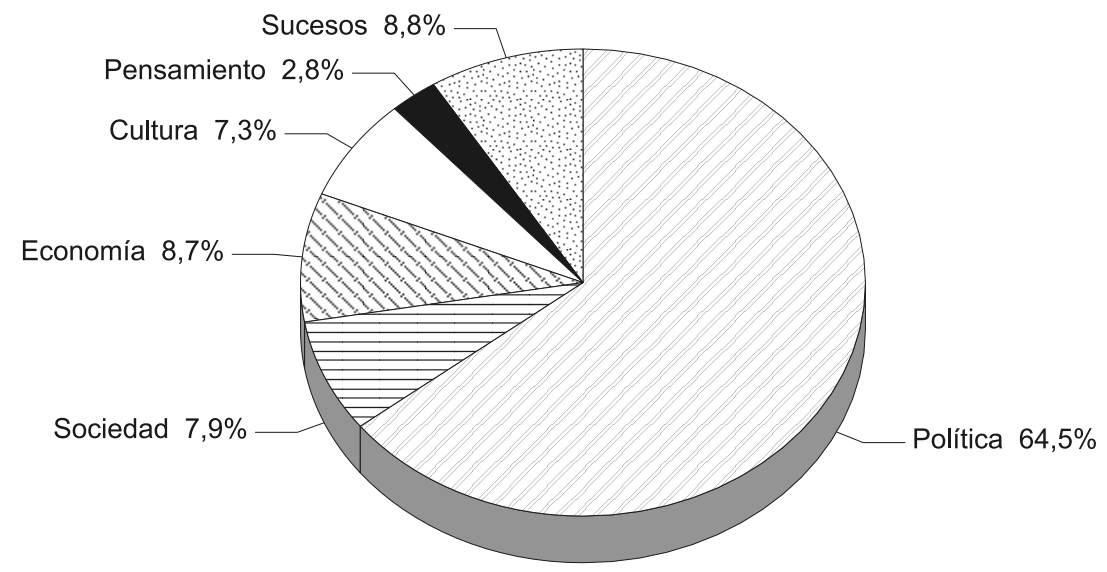

PERÍODO IV 
GRÁFICO XIII

DISTRIBUCIÓN DE NOTICIAS SOBRE IBEROAMÉRICA

La postguerra

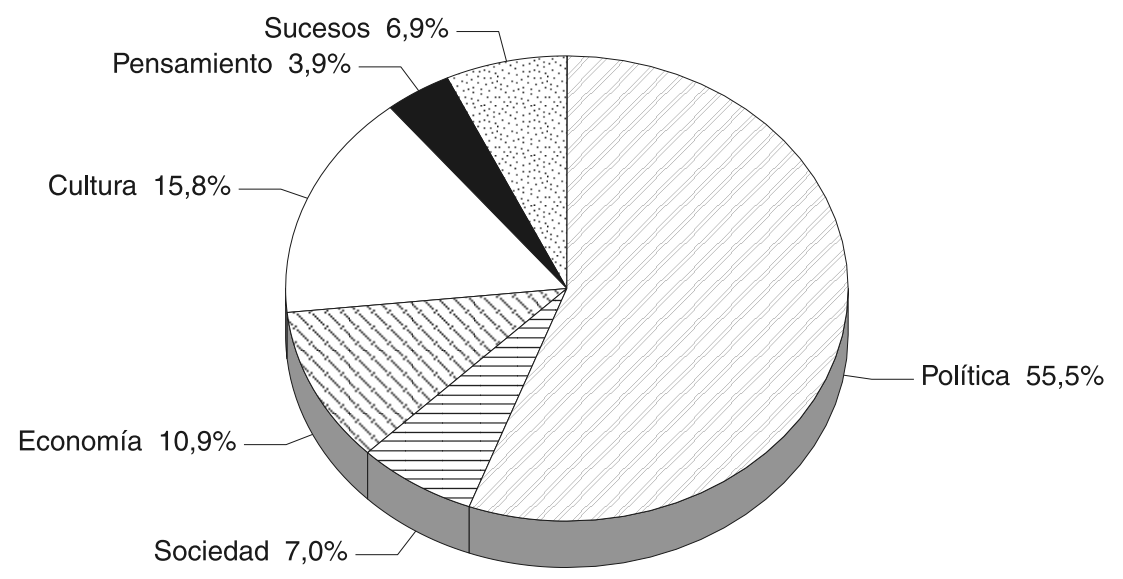

PERÍODO V

GRÁFICO XIV

DISTRIBUCIÓN DE NOTICIAS SOBRE IBEROAMÉRICA

El bloqueo internacional

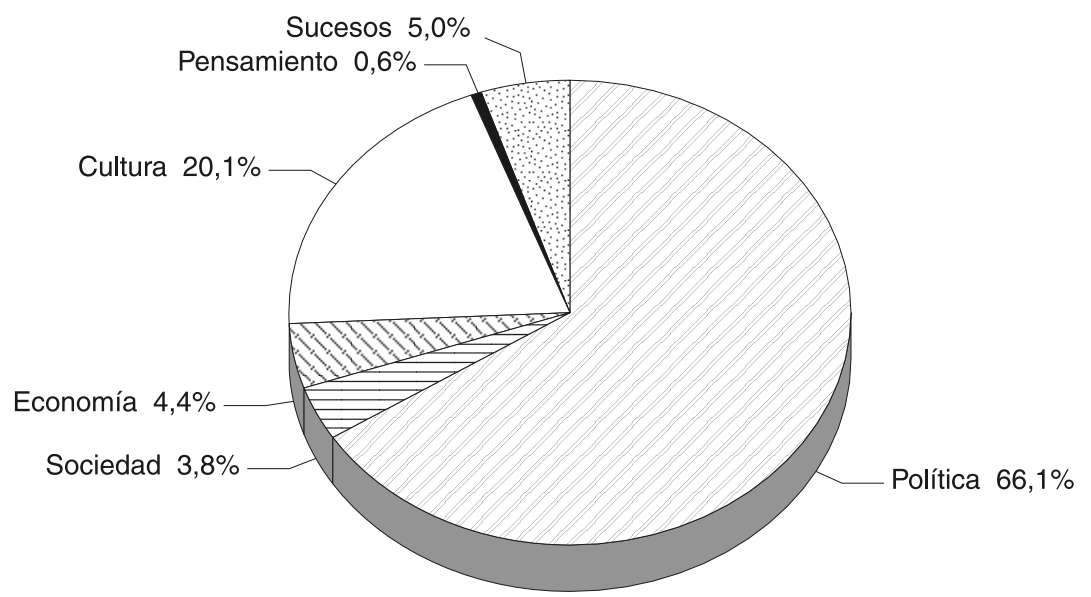

PERÍODO VI 
GRÁFICO XV

DISTRIBUCIÓN DE NOTICIAS SOBRE IBEROAMÉRICA

El franquismo

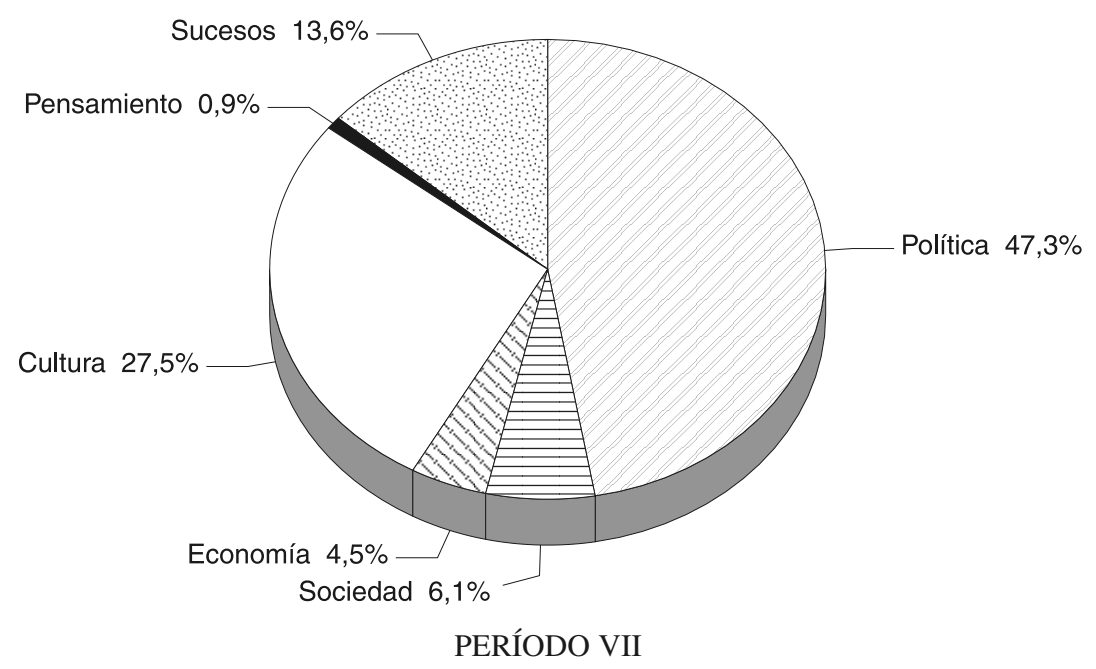

